IZA DP No. 5267

Matched Fundraising:

Evidence from a Natural Field Experiment

Steffen Huck

Imran Rasul

October 2010 


\title{
Matched Fundraising: Evidence from a Natural Field Experiment
}

\author{
Steffen Huck \\ University College London, ELSE \\ and IZA \\ Imran Rasul \\ University College London, ELSE \\ and IZA \\ Discussion Paper No. 5267 \\ October 2010 \\ IZA \\ P.O. Box 7240 \\ 53072 Bonn \\ Germany \\ Phone: +49-228-3894-0 \\ Fax: +49-228-3894-180 \\ E-mail: iza@iza.org
}

Any opinions expressed here are those of the author(s) and not those of IZA. Research published in this series may include views on policy, but the institute itself takes no institutional policy positions.

The Institute for the Study of Labor (IZA) in Bonn is a local and virtual international research center and a place of communication between science, politics and business. IZA is an independent nonprofit organization supported by Deutsche Post Foundation. The center is associated with the University of Bonn and offers a stimulating research environment through its international network, workshops and conferences, data service, project support, research visits and doctoral program. IZA engages in (i) original and internationally competitive research in all fields of labor economics, (ii) development of policy concepts, and (iii) dissemination of research results and concepts to the interested public.

IZA Discussion Papers often represent preliminary work and are circulated to encourage discussion. Citation of such a paper should account for its provisional character. A revised version may be available directly from the author. 


\begin{abstract}

\section{Matched Fundraising: Evidence from a Natural Field Experiment ${ }^{*}$}

We present evidence from a natural field experiment designed to shed light on the efficacy of fundraising schemes in which donations are matched by a lead donor. In conjunction with the Bavarian State Opera House, we mailed 14,000 regular opera attendees a letter describing a charitable fundraising project organized by the opera house. Recipients were randomly assigned to treatments designed to explore behavioral responses to linear matching schemes, as well as the mere existence of a substantial lead donor. We use the exogenous variation in match rates across treatments to estimate the price elasticities of charitable giving. We find that straight linear matching schemes raise the total donations received including the match value, but partially crowd out the actual donations given excluding the match. If charitable organizations can use lead gifts as they wish, our results show they maximize donations given by simply announcing the presence of a lead gift. We contrast our price elasticity estimates with those based on changes in rules regarding tax deductions for charitable giving, as well as from the nascent literature using large-scale natural field experiments on giving.
\end{abstract}

JEL Classification: C93, D12, D64

Keywords: charitable giving, matched fundraising, natural field experiment

Corresponding author:

Imran Rasul

Department of Economics

University College London

Drayton House

30 Gordon Street

London WC1H OAX

United Kingdom

E-mail: i.rasul@ucl.ac.uk

\footnotetext{
* We thank the editor, James Andreoni, and two anonymous referees for very helpful suggestions that have improved the paper enormously. We also thank Sami Berlinski, Stéphane Bonhomme, Guillermo Caruana, Syngjoo Choi, Heike Harmgart, Dean Karlan, John List, Adam Rosen, Georg Weizsäcker, and numerous seminar participants for comments. We gratefully acknowledge financial support from the ESRC and ELSE. We thank all those at the Munich Opera House, Actori, and Maurice Lausberg for making this project possible. This paper has been screened to ensure no confidential information is revealed. All errors remain our own.
} 


\section{Introduction}

This paper presents evidence from a large-scale natural field experiment designed to shed light on the efficacy of fundraising schemes in which individual donations are matched by some lead donor. Vast sums are donated to charitable causes - in 2002, $\$ 241$ billion was given in the US, three quarters of which stemmed from individuals [Andreoni 2006a]. ${ }^{1}$ On the other side of the market, charities themselves spend enormous amounts on fundraising. For example, Kelley [1997] provides evidence that fundraisers spend $\$ 2$ billion a year on strategies to reach funding targets.

One strategy that has become increasingly common among charitable organizations is the use of matched fundraising schemes. Such schemes have long been used by governments, in the form of tax deductions, to encourage giving to good causes. Matched fundraising is also prevalent among private corporations [Eckel and Grossman 2003, Meier 2007]. To give a specific example, the Council for Advancement and Support of Education (1999) survey of 1000 corporations found that almost all had programs to match employee contributions to colleges and universities.

Despite their prevalence in the public, private and charitable sectors, the specific ways in which such matching schemes are framed and implemented have followed largely anecdotal evidence and established rules of thumb, rather than being based on a body of credible evidence from field settings [Dove 2000]..$^{2}$

The paper provides evidence from a natural field experiment to shed light on whether and how individual giving is affected by the presence of matching. Our research design allows us to provide credible evidence on this issue by inducing exogenous variation in the match rates that individuals face when deciding to contribute to the same charitable cause. We build on an earlier generation of studies in public finance, surveyed in Peloza and Steel [2005], that have exploited changes in tax reforms - that correspond to an implicit change in the rate at which contributions are matched by government - to estimate how individual donors respond to changes in the relative price of giving.

We also directly contribute to a nascent literature using large-scale field experiments to understand the efficacy of matched fundraising [Eckel and Grossman 2006, Karlan and List 2007].

In conjunction with the Bavarian State Opera in Munich, in June 2006, we mailed 25,000 opera attendees a letter describing a charitable fundraising project organized by the opera house. The field experiment allows us to implement various matched fundraising schemes in a natural and straightforward way, holding everything else constant. Individuals were randomly assigned to treatments where their individual contribution was matched at either $0 \%, 50 \%$ or $100 \%$, analogous to considerable reductions in the relative price of charitable giving vis-à-vis own consumption. The experimental design also allows us to control for the mere presence of a lead donor who enables

\footnotetext{
${ }^{1}$ Andreoni [2006a] presents evidence from the US that in 1995, $70 \%$ of households made some charitable donation with an average donation of over $\$ 1000$, or $2.2 \%$ of household income. In terms of donations specifically to the arts, in $19959 \%$ of households made some donation with the average household donating around $\$ 200$.

${ }^{2}$ In a series of laboratory and field experiments Eckel and Grossman [2003] provide evidence of how such schemes are significantly more effective in raising donations than the theoretically equivalent rebate scheme [Eckel and Grossman 2003, 2006]. These results are confirmed in another field experiment by Bekkers [2005]. Such results highlight that framing of charitable fundraising requests matters, and that we should not expect fundraisers to use such rebate schemes in practice. Hence our design does not involve any such rebate schemes.
} 
this matching.

The design allows us to estimate the key parameter at the heart of previous studies: the price elasticity of charitable giving. Following the seminal works of Taussig [1967], Feldstein [1975] and Clotfelter [1985], recent studies have, using household data, exploited changes in tax deductions whereby charitable contributions can be used to reduce one's tax burden [Auten et al 1992, Randolph 1995, Tiehen 2001, Auten et al 2002, Fack and Landais 2009]. Peloza and Steel [2005] provide a meta-analysis of tax-based research into charitable giving. Such studies have used various methods to address econometric concerns related to whether changes to the tax system are endogenously determined by expected changes in individual behavior, and whether other changes to the tax system are simultaneously introduced at the same time as changes to tax deductions related to charitable giving.

To circumvent such concerns, a second generation of empirical studies, to which we contribute, have used field experiments to engineer experimental variation in the relative price of charitable giving that potential donors face. Data from such field studies has then also been used to derive price elasticities of charitable giving [Eckel and Grossman 2006, Karlan and List 2007]. ${ }^{3}$

Our main results are as follows. First, despite their ubiquitous prevalence in fundraising campaigns, linear matching schemes do not necessarily pay for the fundraiser. As the charitable good becomes cheaper vis-à-vis own consumption, individuals demand more of it in terms of donations received including the match, but spend less on it themselves in terms of donations given excluding the value of the match. As a result, the own price elasticity of charitable donations received is found to be less than one in absolute value, so that linear matching leads to partial crowding out of donations given.

Second, in calculating the own price elasticity of charitable giving that lies behind this finding, we clarify some of the confusion that has entered the literature. In particular, the previous literature has estimated how donations given respond to the relative price of giving, while we focus on the how donations received respond to the price of giving. The conceptual framework we develop makes clear the former measures the cross price elasticity of consumption with respect to the price of giving, while the latter measures the own price elasticity of charitable giving. To drive home this point, we replicate the alternative methodology of Karlan and List [2007] and, reassuringly, find cross price elasticities that are not significantly different from the baseline elasticity they report. This is despite the two studies examining charitable giving in very different empirical contexts. This congruence of results provides external validity to both studies and helps establish a consistent body of evidence from which charitable organizations can learn.

Third, our design allows us to disentangle the effects of matching schemes from the mere presence of a lead donor that is willing to contribute substantial sums to the charitable cause. This is important because it is empirically well recognized that the mere presence of a lead donor,

\footnotetext{
${ }^{3} \mathrm{~A}$ third class of studies has been based on estimating price effects in laboratory experiments on charitable giving [Andreoni and Miller 2002], or have been based on evidence from both the lab and field. Benz and Meier [2008] present evidence to directly address whether behavior in the lab is informative of how the same individuals behave in the field. They find that while pro-social behavior is slightly accentuated in lab settings, it is highly correlated with behavior in field settings. Finally, Chen et al [2006] explore matching schemes in online fundraising.
} 
or challenge gift, can influence charitable giving [List and Lucking-Reiley 2002, Rondeau and List 2003, Landry et al 2006, Potters et al 2007]. Andreoni [1998] provides a theoretical rationale for such lead gifts. In his framework, lead gifts help coordinate behavior away from a Nash equilibrium in which altruistic givers free-ride on others and optimally do not give, towards an equilibrium in which positive donations are made. Hence lead gifts are used as a coordination device. An alternative theoretical approach views lead gifts as credibility devices, in that lead gifts might send a signal of the project quality to potential donors [Rose-Ackerman 1986, Potters et al 2007, Vesturlund 2003, Andreoni 2006b].

We find that the mere presence of a lead donor - even if their gift is not used to match others' donations - significantly raises the amounts individuals donate, although it has no significant impact on the proportion of recipients that give. Hence, combining this finding with the price elasticity estimates, the key policy implication of our analysis is that if charitable organizations can use lead gifts as they wish, they maximize donations given by simply announcing the presence of a substantial lead donation, rather than trying to leverage this lead gift by offering to match donations received. If on the other hand, lead gifts are provided conditional on matches being offered, the charitable organization is indeed better off offering higher match rates rather than not accepting the lead gift at all.

The paper is organized as follows. Section 2 describes the natural field experiment, and presents a standard model of consumer choice from which to understand behavior across the matching treatments. Section 3 provides descriptive evidence on charitable giving in each treatment. Section 4 presents the econometric analysis of individual decisions of whether and how much to donate in each treatment. Section 5 concludes.

\section{The Natural Field Experiment}

\subsection{Design}

In June 2006 the Bavarian State Opera organized a mail out of letters to 25,000 individuals designed to elicit donations for a social youth project the opera was engaged in, "Stück für Stück". The project's beneficiaries are children from disadvantaged families whose parents are almost surely not among the recipients of the mail out. Hence the fundraising campaign relates to a project that conveys no immediate benefits to potential donors and is therefore more similar to fundraising by aid charities, rather than the typical forms of opera fundraising used to finance projects that benefit opera attendees directly. As recipients do not receive any upfront gifts, this further reduces any role that gift exchange or reciprocity might play in driving donations, as in Falk [2007]. Nor is there much of a role in our design for social recognition to drive donor behavior, as in Andreoni and Petrie [2004] and Frey and Meier [2004], as donors are not publicly announced, and nor is there any role for social influence, as in Shang and Croson [2009], as others' donation levels are 
not revealed. ${ }^{4}$

The recipients were randomly selected from the opera's database of customers who had purchased at least one ticket to attend either the opera or ballet, in the twelve months prior to the mail out. ${ }^{5}$ In this paper, we focus on the 14,000 recipients that were randomly assigned to one of four treatments designed to explore the effect of linear matching fundraising schemes on charitable giving. The remaining 11,000 recipients were assigned to treatments that did not involve linear matching schemes, and hence are not relevant for this study. These additional treatments are analyzed in detail in Huck and Rasul [2009]. The treatments we focus on here vary in how individual donations are matched by the anonymous lead donor.

The mere presence of the lead donor - even absent any matching offer-may serve either as a coordination device to avoid a Nash equilibrium in which no donors give [Andreoni 1998], or as signal of project quality [Rose-Ackerman 1986, Glazer and Konrad 1996, Vesturlund 2003, Andreoni 2006b, Potters et al 2007]. This informs our experimental design in two ways. ${ }^{6}$

First, to estimate the causal impact of the existence of a lead donor per se, we implemented treatments with and without mention of a lead donor. In both treatments, donations were not matched in any way. Second, to estimate the causal impact of exogenously induced changes in the relative price of giving holding constant any effect of a lead donor, we implemented treatments with and without matching. In all treatments the lead donor is mentioned, and the rate at which individual donations are matched is exogenously varied.

The mail out letters were identical in all treatments with the exception of one paragraph. The precise format and wording of the mail out is provided in the Appendix. ${ }^{7}$ The control treatment, denoted T0, was such that recipients were provided no information about the existence of a lead donor, and offered no commitment to match individual donations. The wording of the key paragraph in the letter read as follows,

T0 (Control): This is why I would be glad if you were to support the project with your donation.

This paragraph is manipulated in the other treatments. In the second treatment, denoted $\mathrm{T} 1$, recipients were informed that the project had already garnered a lead gift of $€ 60,000$. The corresponding paragraph read as follows,

\footnotetext{
${ }^{4}$ The project finances small workshops and events for schoolchildren with disabilities or from disadvantaged areas. These serve as a playful introduction to the world of music and opera. It is part of the Bavarian State Opera's mission to preserve the operatic art form for future generations and the project is therefore a key activity to fulfill this mission. As it is not one large event that donations are sought for, but rather a series of several smaller events, it is clear to potential donors that additional money raised can fund additional activity. In other words, the marginal contribution will always make a difference to the project.

${ }^{5}$ We initially remove non-German residents, corporate donors, formally titled donors, and recipients to whom we cannot assign a gender - typically couples, from the database.

${ }^{6}$ Romano and Yildirim [2001] propose a third explanation in which such announcements are a means of inducing a sequential game among donors as an alternative to having them contribute simultaneously. Such a rationalization for announcement by charities requires agents to have utility functions with some element of warm glow.

${ }^{7}$ All letters were designed and formatted by the Bavarian State Opera's staff, and addressed to the individual as recorded in the database of attendees. Each recipient was sent a cover letter describing the project, in which one paragraph was randomly varied in each treatment. On the second sheet of the mail out further details on the "Stück für Stück" project were provided. Letters were signed by the General Director of the opera house, Sir Peter Jonas, and were mailed on the same day-Monday 19th June 2006.
} 
T1 (Lead Donor): A generous donor who prefers not to be named has already been enlisted. He will support "Stück für Stück" with €60,000. Unfortunately, this is not enough to fund the project completely which is why I would be glad if you were to support the project with your donation.

The control and lead donor treatments differ only in that in the latter recipients are informed of the presence of a lead donor. There is no offer to match donations in any way in either treatmenta donation of one Euro corresponds to one Euro being received by the opera house. Comparing behaviors over $\mathrm{T} 0$ and $\mathrm{T} 1$ sheds light on whether and how individuals respond to the existence of such lead donors. ${ }^{8}$

The final two treatments provided recipients with the same information on the presence of a lead donor as in treatment $\mathrm{T} 1$, but varied the rate at which donations would be matched. Individuals assigned to these treatments effectively face a lower relative price for the charitable good vis-à-vis own consumption, than do individuals in treatments T0 and T1. The first matching treatment informed recipients that each donation would be matched at a rate of $50 \%$, so that giving one Euro would correspond to the opera receiving $€ 1.50$ for the project. The corresponding paragraphs in the letter read as follows,

T2 (50\% Matching): A generous donor who prefers not to be named has already been enlisted. He will support "Stück für Stück" with up to $€ 60,000$ by donating, for each Euro that we receive within the next four weeks, another 50 Euro cent. In light of this unique opportunity I would be glad if you were to support the project with your donation.

The next treatment, denoted T3, was identical to T2 except the match rate was set at 100\%, so the corresponding paragraph in the mail out letter read as follows,

T3 (100\% Matching): A generous donor who prefers not to be named has already been enlisted. He will support "Stück für Stück" with up to $€ 60,000$ by donating, for each donation that we receive within the next four weeks, the same amount himself. In light of this unique opportunity I would be glad if you were to support the project with your donation.

Comparing behavior in the linear matching treatments T2 and T3 to T1 allows us to estimate the own price elasticity of donations received, as the price of giving relative to the price of own consumption is what is being experimentally varied. An important distinction between our experimental design and that of Karlan and List [2007] is that when calculating price elasticities using treatments $\mathrm{T} 1$ to $\mathrm{T} 3$, all treatments provide recipients information on the presence of the lead donor. An alternative set up, followed in Karlan and List [2007] is to have a control treatment in which no lead donor is announced, like treatment T0 above. Price elasticities can still be derived from a comparison of T0 to the matching treatments T2 and T3, although this might confound the effects of the lead donor and the matching offer. Estimating the pure effect of the lead donorfrom a comparison of T0 and T1 - allows us to isolate the first such effect. Finally, to strengthen the external validity of both field experiments, we replicate Karlan and List's [2007] approach and calculate price elasticities from a comparison of T0 to T2 and T3. As shown later, we find cross

\footnotetext{
${ }^{8}$ Andreoni [2006b] highlights the problem that lead donors have incentives to overstate the quality of the project. Since such deception cannot arise in equilibrium it follows that lead gifts need to be extraordinarily large to be credible signals of quality. In our study the lead gift is 400 times larger than the average donation.
} 
price elasticities that are not significantly different from the baseline elasticity they report. This is despite the two studies examining charitable giving in very different empirical contexts.

Three points are worth bearing in mind regarding the experiment. First, the opera had no explicit fundraising target in mind, nor was any such target discussed in the mail out. Moreover, the money raised for the project is not used to finance one large event but rather a series of several smaller events, as made clear in the mail out letter. Hence the project is of a linearly expandable nature such that recipients know that marginal contributions will make a difference..$^{9,10}$

Second, recipients are told the truth. The lead gift was actually provided and each matching scheme was implemented. The value of matches across all treatments was capped at $€ 60,000$ which ensured subjects were told the truth even if the campaign was more successful than anticipated. Crucially, this holds the commitment of the lead donor and, hence, the quality signal, constant across treatments.

Third, recipients were told the matching schemes would be in place for four weeks after receipt of the mail out. Although in principle such a deadline might affect behavior, we note that-(i) over $97 \%$ of recipients that donated did so during this time frame and the median donor gave within a week of the mail out; (ii) we find no evidence of differential effects on the time for donations to be received between any treatments, in which no such deadline was announced. ${ }^{11}$

\subsection{Conceptual Framework}

A standard consumer theory framework can be used to describe the individual utility maximization problem under each treatment. This makes precise what can be inferred from a comparison of behavior across matching treatments. We assume individuals have complete, transitive, continuous, monotone, and convex preferences over two arguments, their private consumption, $c$, and the donation received by the project, $d_{r}$. Each individual's utility maximization problem is,

$$
\max _{d_{r}} u\left(c, d_{r}\right) \text { subject to } c+d_{g} \leq y, c, d_{g} \geq 0, \text { and } d_{r}=\lambda d_{g}
$$

where the first constraint ensures consumption can be no greater than income net of any donation given, $y-d_{g}$; the second constraint requires consumption and donations given to be non-negative; and the third constraint denotes the matching scheme that translates donations given into those received by the opera house. Under linear matching treatments, $\lambda$ corresponds to the match rate.

\footnotetext{
${ }^{9}$ The effects of such seed money are in general ambiguous and depend on whether individuals believe the project is far from, or close to, its designated target, and whether these beliefs encourage or discourage donations [List and Lucking-Reiley 2002]. Rondeau and List [2008] present experimental evidence on the effects of lead donations in the presence of explicit targets.

${ }^{10}$ If recipients have the same belief that others had donated to such an extent that the $€ 60,000$ of the lead donor was already exhausted and so the match scheme would no longer be in place, there should be no difference in behaviors across treatments T2 and T3. This hypothesis is rejected by the data.

${ }^{11}$ As recipients were drawn from the database of attendees to the opera, it might be the case that recipients know each other. Having knowledge of whether another opera attendee had received the mail out, and the form of the letter they received, may in principle lead to some changes in behavior if there are strong peer effects in charitable giving. We, however, expect such effects to be qualitatively small and, indeed, the opera house received no telephone queries regarding treatment differences.
} 
This utility function captures the notion that potential donors care about their own consumption and the marginal benefit their donation provides. Given the linearly expandable nature of the project, this marginal benefit relates to $d_{r}$.

Figure 1 graphs the budget sets induced by the matching treatments in $\left(y-d_{g}, d_{r}\right)$-space. In the control and lead donor treatments (T0 and T1) the budget line has vertical intercept $y$ and a slope of minus one as for each Euro given by an individual, the project receives one Euro $\left(d_{r}=d_{g}\right)$. However, if individuals infer the project is of high quality due to the existence of a lead donor, the marginal rate of substitution between net income and donations received may be altered and so affect behavior on both the extensive and intensive margins.

The linear matching schemes vary the price of donations relative to own consumption so that with the $50 \%$ match rate in $\mathrm{T} 2, \lambda=1.5$, and with the $100 \%$ match rate in $\mathrm{T} 3, \lambda=2$. In both cases the budget set pivots out with the same vertical intercept. A comparison of treatments T1, $\mathrm{T} 2$, and T3 then provides a series of estimates of the own price elasticity of charitable donations received as the match rate varies, holding constant information on the lead donor. Consider an increase in the match rate from $\lambda$ to $\lambda^{\prime}$. As the price of consumption is normalized to one, the relative price of donations received, $p$, falls from $\frac{1}{\lambda}$ to $\frac{1}{\lambda^{\prime}}$ so the own price elasticity of donations received is,

$$
\epsilon_{d_{r}, p}=\left(\frac{\Delta d_{r}}{\Delta p}\right) /\left(\frac{d_{r}}{p}\right)=\left(\frac{\Delta d_{r}}{\frac{1}{\lambda}-\frac{1}{\lambda^{\prime}}}\right) /\left(\frac{d_{r}}{\frac{1}{\lambda}}\right) .
$$

where $d_{r}$ is the average donation received in the baseline treatment with match rate $\lambda$, and $\Delta d_{r}$ is the change in donations received as the match rate increases from $\lambda$ to $\lambda^{\prime}$. As the price of own consumption is normalized to one, the price of donations given is always equal to one independent of the match rate. While we focus attention on the own price elasticity of donations received, we later also calculate the implied cross price elasticity of donations given with respect to the price of giving, in order to directly compare our results to those in Karlan and List [2007].

Two point predictions on this own price elasticity of donations warrant special attention. First, if recipients are engaged in pure donation targeting - where preferences are such that individuals choose a particular $d_{r}$ independent of the price of donations received - then moving from a match rate of $\lambda$ to $\lambda^{\prime}$ implies $\Delta d_{r}=0$ and $\Delta d_{g}=\frac{\lambda-\lambda^{\prime}}{\lambda^{\prime}} d_{g}<0$. Hence the own price elasticity of donations received is $\epsilon_{d_{r}, p}=0$ so the increased match rate leads to full crowding out of donations given.

Second, suppose preferences are characterized by pure warm glow - where individuals only care about the donation given rather than that actually received. If the match rate then increases from $\lambda$ to $\lambda^{\prime}$ this leads to $\Delta d_{g}=0$ and $\Delta d_{r}=\left(\lambda^{\prime}-\lambda\right) d_{g}>0$ so the own price elasticity of donations received is $\epsilon_{d_{r}, p}=-\frac{\lambda^{\prime}}{\lambda} \cdot{ }^{12}$

As our research design does not restrict the behavior of individuals in any way, it is possible for them to display behavior consistent with there being crowding out or crowding in of donations given, or even of donations received being a Giffen good. Figure 2 summarizes the possible

\footnotetext{
${ }^{12}$ The pure warm glow model, a special case of the preferences described in Andreoni [1990], implies donors care only about their own consumption $\left(y-d_{g}\right)$ and their donation given $\left(d_{g}\right)$ but not about the donation received $\left(d_{r}\right)$. In this special case all budget sets would be materially identical for donors. However, as documented later, the data rejects this hypothesis.
} 
inferences that can be made about individual preferences at different values of the estimated own price elasticity of donations received. ${ }^{13}$

\section{Descriptives}

\subsection{Sample Characteristics and Treatment Assignment}

Table 1 tests whether individuals differ across treatments in the individual characteristics obtained from the opera's database. For each observable, Table 1 reports the $p$-values on the null hypothesis that the mean characteristics of individuals in the treatment group are the same as in the control group T0. There are almost no significant differences along any dimension between recipients in each treatments, so that individuals appear randomly assigned into treatments on observables.

Columns 1 and 2 show that there is an almost equal split of recipients across treatments, and that close to half the recipients are female. Columns 3 to 6 provide information on individuals' attendance at the opera. This is measured by the number of tickets the individual has ordered in the twelve months prior to the mail out, the number of separate ticket orders that were placed over the same period, the average price paid per ticket, and the total amount spent. Individuals in the sample typically purchase around six tickets in the year prior to the mail out in two separate orders. The average price per ticket is around $€ 86$ with the annual total spent on attendance averaging over $€ 400$. In Column 7 we use information on the zip code of residence of individuals to identify that $40 \%$ of recipients reside within Munich, where the opera house is located. The majority of individuals have attended the opera in the six months prior to the mail out.

Two further points are of note. First, the number of tickets bought, the number of orders placed, and whether or not a person lives in Munich, can proxy an individual's affinity to the opera. This may in turn relate to how they trade-off utility from consumption for utility from donations received by the opera for the "Stück für Stück" project. In contrast, the average price per ticket bought might better proxy individual income. We later exploit this information to shed light on whether on the extensive margin, donors differ from non-donors predominantly in terms of their affinity to the opera, or in terms of their incomes. Of course, we cannot rule out the existence of 'opera buffs' whose expenditures on opera tickets are beyond their means. Insofar as such individuals exist, the average ticket price might also reflect an element of affinity.

Second, recipients are not representative of the population - they attend the opera more frequently than the average citizen and are likely to have higher disposable incomes. This is further reinforced by the information presented in Column 9, where we have matched in information on house rental prices by zip code. We see that the average recipient resides in zip codes in which rental prices - per square metre per month - are high relative to Germany as a whole. Our analysis sheds light on how such selected individuals donate towards a project that is being directly

\footnotetext{
${ }^{13}$ Under standard consumer theory, donations received can only fall as the relative price of giving falls if the good is Giffen. However, there exist other hypotheses of why donations received might fall in such circumstances - for example if the offer of a match signals to potential donors that the charity mistrusts them [Rousseau 1995, Falk and Kosfeld 2006], or prosocial behaviors being crowded out by monetary incentives [Benabou and Tirole 2006].
} 
promoted by the opera house, and how sensitive they are to relative price changes. To the extent that other organizations target charitable projects towards those with high affinity to the organization as well as those who are likely to have high income, the results have external validity in other settings. Moreover, while the non-representativeness of the sample may imply the observed levels of response or donations likely overstate the response among the general population, we focus attention on differences in behavior across matching treatments that purge the analysis of the common characteristics of sample individuals. ${ }^{14}$

\subsection{Behavior on the Extensive Margin}

Table 2 provides evidence on the observable characteristics of donors and non-donors split within each treatment. We report the mean and standard error of each characteristic, as well as the $p$-value on the null hypothesis that the characteristic is the same among donors and non-donors in the same treatment. As a point of comparison, the first row refers to all recipients (donors and non donors) across all treatments T0 to T3.

Columns 1 and 2 show that response rates vary from $3.5 \%$ to $4.2 \%$ across treatments, which are almost double those in comparable large-scale natural field experiments on charitable giving [Eckel and Grossman 2006, Karlan and List 2007]. ${ }^{15}$ Indeed, a rule of thumb used by charitable organizations is to expect response rates to mail solicitations of between $.5 \%$ and $2.5 \%$ [de Oliveira et al 2010].

To better understand the correlates of giving, the table shows the p-value on the null that on any given observable dimension, donors and non-donors are equal. On the relationship between affinity to the opera and giving as the relative price of giving varies, we note that individuals that have purchased more tickets in the year prior to the mail out, have placed more separate orders over the same time period, and have last attended the opera more recently are significantly more likely to donate in each and every treatment. These results suggest that affinity to the opera house - as proxied along these dimensions - is strongly correlated to behavior along the extensive margin of whether to donate or not.

On the relationship between income and giving, we find that the average price per ticket does not differ significantly between donors and non-donors in any of the treatments. Munich residents are not more likely to respond in each treatment. The last column shows that in each and every treatment, the rental rate of donors and non donors is not significantly different. Taken together, these three pieces of evidence suggest that income proxies are not very correlated with behavior on the extensive margin of charitable giving, as the relative price of giving varies. ${ }^{16}$

\footnotetext{
${ }^{14}$ This is the case if treatment effects are found to be homogeneous, which is indeed the case in our experiment. Otherwise in the presence of heterogeneous treatment effects we can expect the estimates to vary in other settings with a different underlying sample composition.

${ }^{15}$ One explanation for the high response rates we obtain may be that the Bavarian State Opera has not previously engaged in fundraising activities through mail outs, nor is the practice as common in Germany as it is in the US.

${ }^{16}$ This has been noted previously in studies on the relation between tax rules and charitable giving [Peloza and Steel 2005]. For example, Cermak et al [2004] find that motives such as reciprocity, family tradition and social ties are predictors of giving among high income individuals but that tax incentives are not.
} 
Table 3 provides descriptive evidence on whether a donation is given by treatment. Column 1 shows that, despite large variations in the relative price of giving, the response rates in T2 or T3 are not significantly different from those in the lead donor treatment $\mathrm{T} 1$ at conventional levels. However, it is important to note that given charitable fundraising drives typically elicit low response rates, even in such large samples there is low power to detect significant changes on the extensive margin. Focusing therefore on the point estimates, we see that response rates do rise when a $50 \%$ match rate is introduced in $\mathrm{T} 2$, although the response rate does not change when this match rate is increased to $100 \%$ in T4. In proportionate terms, the increase in response rate from $3.5 \%$ to $4.2 \%$ moving from $\mathrm{T} 1$ to $\mathrm{T} 2$ corresponds to a $20 \%$ increase over the baseline control treatment. Hence the data is suggestive of there being some individuals who are just on the margin of donating in treatment T2, namely those for whom the marginal rate of substitution between own consumption and donations received, is such that $-\frac{1}{2}<\left.M R S_{c, d_{r}}\right|_{d_{r}=0}<-1$.

\subsection{Behavior on the Intensive Margin}

Table 3 provides descriptive evidence on donations given and received by matching treatment. For each statistic we report its mean, its standard error in parentheses, and whether it is significantly different from that in the control and lead donor treatments, T0 and T1 respectively. Figure 1 provides a graphical representation of the outcomes of each matching treatment.

Columns 2 and 3 show that the total amounts donated and actually received vary across treatments. Among the recipients in these treatments, over $€ 57,000$ was donated by 585 donors, corresponding to a mean donation given $\left(d_{g}\right)$ of $€ 99$. Including the value of the match, over $€ 80,000$ was raised for the project, corresponding to a mean donation received $\left(d_{r}\right)$ of $€ 137 .{ }^{17}$

Column 4 shows that in the control treatment T0, the average donation given is $€ 74.3$. In the lead donor treatment $\mathrm{T} 1$, this rises significantly to $€ 132$. The near doubling of donations given can only be a response to the presence of a lead donor - the relative price of donations received by the opera house vis-à-vis own consumption is unchanged. The result is not driven by outliersColumn 5 shows the median donation is also significantly higher in T1 than in T0. Hence when calculating price elasticities, it will be important to hold constant information on the presence of the lead donor.

To get a better sense of the distribution of donations, Figure 3 shows the cumulative distribution of donations given by matching treatment. To avoid distorting the figure, we cap donations given to $€ 500.98 \%$ of donations are of $€ 500$ or less.

The comparison of outcomes between the control treatment T0 and lead donor treatment T1 suggests the marginal rate of substitution between consumption and donations received is altered when individuals are aware of an anonymous lead donor who has already pledged a substantial donation to the project. While such a lead gift does not induce new donors to enter - the response rates do not significantly differ between $\mathrm{T} 0$ and $\mathrm{T} 1$ - recipients who like the project to begin with

\footnotetext{
${ }^{17}$ In the full sample of 25,000 recipients in all treatments, more than $€ 120,000$ were donated, fully exhausting the $€ 60,000$ of the lead donor.
} 
like it even more when they observe that somebody else is already strongly committed to it.

On linear matching schemes, we see from Column 4 that as the relative price of donations received falls, the average donation received, $d_{r}$, rises. The average donation received increases to $€ 151$ in $\mathrm{T} 2$ with a $50 \%$ match rate, and to $€ 185$ in T3 with a $100 \%$ match rate. Importantly, as shown in Figure 1 and Column 6 of Table 3, as the match rate increases, the donations given, $d_{g}$, fall. The average donation given falls from $€ 132$ in the control treatment $\mathrm{T} 1$ to $€ 101$ in $\mathrm{T} 2$ with a $50 \%$ match rate, and to €92.3 in T3 with a $100 \%$ match rate. Column 7 reiterates that these differences are not driven by outliers - the median donation given is significantly lower in treatments T2 and T3 than the control treatment T1.

Therefore, linear matching does not crowd in donations - rather there is partial crowding out of donations given to an extent that, although donations received increase, they do so less than proportionately to the fall in the relative price of the charitable good. The results highlight that it is of crucial importance to be able to decompose individual responses as those being driven by the mere presence of the lead donor, and those caused by exogenous variation in the match rate. If charitable organizations can use lead gifts as they wish (so that the matching schemes in treatments T0, T1, T2 and T3 are all options), then the descriptive evidence suggests they maximize donations given by simply announcing the presence of a lead gift, but not seeking to use it by offering to match donations given. However, if lead gifts are provided conditional on matches having to be offered (so treatment $\mathrm{T} 1$ is no longer an option), then the charitable organization is indeed better off offering higher match rates rather than not accepting the lead gift at all.

\section{Evidence}

\subsection{Method}

We now focus on treatments $\mathrm{T} 1$ to $\mathrm{T} 3$ to present regression evidence. This allows us to: (i) see whether the earlier results are robust to the inclusion of observable recipient characteristics; (ii) estimate the price elasticities of charitable giving; (iii) check for whether recipient's behavior is driven by particular motives such as pure warm glow or donation targeting. On the extensive margin of giving, we estimate the following probit model for whether any donation is given $\left(D_{i}=1\right)$ or $\operatorname{not}\left(D_{i}=0\right)$,

$$
\operatorname{prob}\left(D_{i}=1\right)=\Phi\left(\beta_{2} T 2_{i}+\beta_{3} T 3_{i}+\gamma_{1} X_{i}\right)
$$

Whether $i$ donates or not depends on the budget set she faces as embodied in the treatment she is assigned to, $T 2_{i}$ or $T 3_{i}$, with the omitted treatment assignment being to $T 1$. Given random

assignment this is orthogonal to the error term $u_{i}$ so $\left(\widehat{\beta}_{2}, \widehat{\beta}_{3}\right)$ provide consistent estimates of each treatment effect on the extensive margin of giving relative to the omitted lead donor treatment $T 1$. We control for individual characteristics $X_{i}$, to reduce the sampling errors of the treatment effect estimates [Hirano et al 2003]. We report marginal effects that are evaluated at the mean, 
and calculate robust standard errors throughout.

On the intensive margin of charitable giving, the central concern is that even with random assignment into treatments, we cannot in general make valid causal inferences conditional on donations being positive because those that choose to donate are likely to differ from those that choose not to donate. Table 2 already highlights the observable dimensions along which donors differ to non donors. We address this sample selection issue in two ways. First, we estimate for the entire sample of recipients the following OLS specification for the donation received by the opera house from recipient $i, d_{r i}$,

$$
d_{r i}=\delta_{2} T 2_{i}+\delta_{3} T 3_{i}+\gamma_{2} X_{i}+v_{i}
$$

so that $d_{r i}=0$ for non donors, $v_{i}$ is a disturbance term and all other controls are as previously defined. We calculate robust standard errors throughout. Under the assumption of no spillover effects between treatments, the parameters of interest $\left(\widehat{\delta}_{2}, \widehat{\delta}_{3}\right)$ measure the average treatment effect on the donation received of individual $i$ being assigned to treatment T2 or T3 respectively, relative to the omitted control treatment T1. ${ }^{18}$

When applying the OLS model (4) to positive donations, inference can be made only under the condition $E\left[v_{i} \mid T 2_{i}, T 3_{i}, X_{i}, D_{i}=1\right]=0$ [Angrist 1997]. Intuitively, we require unobserved determinants of the amount donated, conditional on giving, treatment assignment and observable characteristics, to be orthogonal to unobserved determinants of the decision to donate. We provide some suggestive evidence in support of this assumption utilizing results from a follow-up experiment with the same Opera house, described in more detail in Huck and Rasul [2010].

In order to estimate the treatment effects conditional on a positive donation being made, we specify a hurdle model which takes account of the fact that the initial decision to donate $\left(D_{i}=0\right.$ or 1$)$ may be separated from the decision of how much to donate, namely, the choice over $d_{r}$ conditional on $D_{i}=1$. A simple two-tiered model for charitable giving has, as a first stage, the probit model above in (3). At the second stage, we assume donations received are log normally distributed conditional on any donation being given, namely, $\log \left(d_{r i}\right) \mid\left(T_{i}, X_{i}, D_{i}=1\right) \sim$ $N\left(\beta_{3} T_{i}+\gamma_{2} X_{i}, \sigma^{2}\right)$. The maximum likelihood estimator of the second stage parameters, $\left(\beta_{3}, \gamma_{2}\right)$, is then simply the OLS estimator from the following regression,

$$
\log \left(d_{r i}\right)=\delta_{2} T 2_{i}+\delta_{3} T 3_{i}+\gamma_{3} X_{i}+z_{i} \text { for } d_{r i}>0
$$

where it is assumed $z_{i}$ is a classical disturbance term [Wooldridge 2002]. We calculate robust standard errors throughout. For each treatment, we therefore present both the OLS and hurdle model estimates, as well as a Tobit specification that utilizes both zero and positive donations.

\footnotetext{
${ }^{18} v_{i}$ may in part capture determinants of charitable giving such as guilt or shame. We are implicitly assuming that such motives do not interact with the matching treatments so that comparisons of the change in behavior between treatments is informative.
} 


\subsection{Results}

Table 4 presents the results. We compare responses on the extensive and intensive margin of recipients in treatment T2, which introduces a 50\% match rate, and T3, which introduces a $100 \%$ match rate, relative to treatment $\mathrm{T} 1$ that involves no match rate. In all treatments, recipients are aware of the existence of a lead donor, and so comparisons of behavior to T1 isolate the pure relative price effects of the linear matching fundraising schemes.

Column 1 shows that, in line with the descriptive evidence, recipients are no more likely to respond to either price matching treatment than to the lead donor treatment, T1. This suggests there are few individuals who are just on the margin of donating in treatment T2, namely those for whom the marginal rate of substitution between own consumption and donations received, is such that $-\frac{1}{2}<\left.M R S_{c, d_{r}}\right|_{d_{r}=0}<-1$.

On the intensive margin, the OLS estimates in Column 2 show that relative to recipients in the lead donor treatment $\mathrm{T} 1$ which involves no match rate-(i) larger donations are received in treatment T2, although this is not quite significantly different from zero at conventional levels; (ii) significantly larger donations are received in treatment T3. These results are confirmed using the hurdle model specification in Column 3 which takes account only of positive donations. Column 4 presents estimates from a Tobit specification that uses all observations from treatments T1 to T3. This finds donations received to be significantly higher in treatments T2 and T3. ${ }^{19,20}$

At the foot of Column 3 we report the implied own price elasticity of donations received, $\epsilon_{d_{r}, p}$. This varies from -.534 when we consider the behavioral response in T2 vis-à-vis T1, to -1.12 when we consider the behavioral response in T3 vis-à-vis T2. We also use these estimated own price elasticities to shed light on whether individuals behave as if they are motivated by pure warm glow $\left(\epsilon_{d_{r}, p}=-\frac{\lambda^{\prime}}{\lambda}\right)$ or by donation targeting $\left(\epsilon_{d_{r}, p}=0\right)$. Both forms of behavior are rejected by the data - in five out of six tests the implied price elasticities differ significantly from these values at conventional levels of significance, as reported at the foot of Column $3 .^{21}$

Viewed through the lens of consumer theory, our results deliver a positive message for ortho-

\footnotetext{
${ }^{19}$ An alternative interpretation of the results might be that recipient's behavior is driven by the inferences they make about the lead donor over these treatments rather than any changes in relative prices. For example, in T1 the lead donor effectively commits to provide $€ 60,000$ irrespective of the behavior of others. In T2 the lead donor commits to providing $€ 60,000$ only if other donors provide $€ 120,000$ given the match rate. Similarly, in T3 the lead donor commits to providing $€ 60,000$ only if other donors provide $€ 60,000$. In other words, the level of commitment of the lead donor that recipients may infer is greatest in $\mathrm{T} 1$, second highest in $\mathrm{T} 3$, and lowest in T2. In consequence, recipients might infer the level of baseline funding for the project is higher in $\mathrm{T} 1$, which would imply lower giving in T2 and T3 if marginal returns to total funding are diminishing. Three pieces of evidence contradict such an interpretation-(i) donations received monotonically decrease in their relative price - moving from T1 to T2 to T3; (ii) donations given fall as the strength of the commitment rises moving from T2 to T3; (iii) in actuality, the lead donation of $€ 60,000$ was exhausted by the donations from the original 25,000 mail out recipients.

${ }^{20}$ We found no robust evidence that these treatment effects vary by observable characteristics along either the extensive and intensive margins. In other words, recipients with more affinity to the opera, or those that pay a higher price per ticket on average, are no more sensitive to the price of charitable giving than other individuals.

${ }^{21}$ The fact that individuals respond to price changes also rules out the hypothesis that recipients believe their donation contributes little to the charitable project. This occurs in any model of giving where consumer preferences are concave in total project size and there are a large number of consumers, as in the impure altruism model [Andreoni 1990]. However, this is unlikely to be a good representation of the project in this setting because the project is of a linearly expandable nature such that recipients know that marginal contributions matter.
} 
dox economic theory. Consumer behavior, on both the extensive and intensive margins, can be rationalized within a standard model of consumer choice in which individuals have preferences defined over own consumption and charitable donations received by the project. We find no evidence of particular behaviors such that choices are motivated either purely by warm glow, or that individuals target a certain amount of donations to give irrespective of the budget set faced.

Overall, the data from the price matching treatments therefore supports the demand for donations received to be decreasing in their own price, and there being partial crowding out of donations given $\frac{\lambda-\lambda^{\prime}}{\lambda^{\prime}} d_{g}<\Delta d_{g}<0$ and $\Delta d_{r}>0$. Hence, despite their ubiquitous prevalence in fundraising campaigns, linear matching schemes might harm the fundraiser as they reduce donations given. Certainly, if substantial lead gifts are given unconditionally, so that the charity seeks to maximize donations given excluding the match, then the charitable organization is better off announcing the existence of the lead gift, rather than trying to leverage it using some matching scheme. If on the other hand the lead gift is given conditional on some matching scheme being used, then our results suggest the charity is better off matching at $100 \%$ rather than at $50 \%$.

Previous studies have varied in the empirical method used to estimate price elasticities, which is reflected in the wide range of estimates proposed. Studies on giving based on tax returns typically estimate the own price elasticity of giving, including the value of the implicit match. Such studies that use cross sectional survey data typically find a price elasticity between -1.1 and -1.3 [Andreoni 2006a]. Panel data studies [Auten et al 1992, Randolph 1995, Auten et al 2002, Tiehen 2001] using US data on tax returns over a period spanning two tax reforms, provide potentially exogenous sources of variation from which to identify price elasticities. Auten et al [1992] find price elasticities to be -1.11. Randolph [1995] finds short run elasticities to be higher than cross sectional estimates at -1.55, although Auten et al [2002] find the reverse, with elasticities ranging from -.40 to -.61 depending on the empirical method used. Tiehen [2001] constructs a cohort panel from cross sections of household surveys using the method set out in Deaton [1985], and finds price elasticities between -.9 to -1.1 . Fack and Landais [2009] use changes in tax incentives in France to estimate price elasticities between -.2 and -.6.

Finally, Peloza and Steel [2005] providing a meta-analysis of tax-based research into charitable giving. Their analysis is based on 69 studies almost exclusively based on US data, covering cross sectional and panel data estimates and exploiting temporary and permanent tax changes. Across all studies, they report an average price elasticity of -1.1 once outliers are excluded, with panel based approaches having a mean estimate of -1.0 and cross sectional estimates being higher in absolute value at -1.5 , although not significantly different.

Own price elasticities of charitable giving have also been estimated in earlier natural field experiments. Eckel and Grossman [2006] estimate a higher price elasticity around -1 as match rates vary from 25 to $33 \%$, and find this to be significantly larger in absolute value than consumer responses to the equivalent rebate. In comparison to Karlan and List [2007], there are two important differences between the elasticities they report and those we calculate. First, they calculate elasticities from a comparison of treatments with a lead donor and a matching scheme relative to a control in which neither is offered - as in our control treatment T0. Second, they calculate 
how donations given respond to the relative price of giving, while we focus on the how donations received respond to the price of giving. Our conceptual framework makes clear the former measures the cross price elasticity of consumption with respect to the price of giving, while the latter measures the own price elasticity of charitable giving.

Column 5 estimates (5) using the donation given to calculate the implied cross price elasticity of consumption with respect to the price of charitable giving. Column 6 replicates the methodology of Karlan and List [2007] using the control treatment T0 as the base category, not the lead donor treatment $\mathrm{T} 1$ in which potential recipients are aware of the lead gift. Reassuringly, we then find cross price elasticities that are not significantly different from the baseline elasticity reported in Karlan and List [2007], -.225 . These elasticities are far lower than those found in the tax based studies or other field experiments cited above, but to reiterate, these estimates are reconcilable once it is recognized that they do not measure precisely the same underlying parameter.

\section{Conclusions}

We have presented evidence from a natural field experiment designed to shed light on the efficacy of matched fundraising schemes. The key insights of practical use from any fundraiser's point of view are that: (i) announcing the mere presence of a significant lead donor substantially increases donations given, although does not raise response rates; (ii) straight linear matching schemes raise the total donations received including the match value, but partially crowd out the actual donations given excluding the match; (iii) if charitable organizations can use lead gifts as they wish and only seek to maximize donations given, our results show they maximize donations given by simply announcing the presence of a lead gift; (iv) if the lead gift is offered conditional on some matching being in place, then donations received are maximized by implementing such a matching scheme than not accepting the gift at all.

These results beg the question of why fundraisers are so often observed employing matched fundraising. ${ }^{22}$ The first explanation arises from competitive pressures. From a lead donors point of view, given competition between fundraisers, those that offer to match donations are more likely to receive lead gifts in the first place. Moreover, from an individual small donors point of view, given competition between fundraisers, donors might prefer to give to those causes where matching is in place.

Second, the lead donor might herself also have some uncertainty over the project quality. Through offering a lead gift with matching, the lead donor can, in some sense, aggregate the signals all small donors have on the project quality, and therefore only contribute if others also think the project is worthwhile.

A third explanation for the prevalence of linear matching schemes might be that the same organization is typically not observed experimenting with different fundraising schemes and thus

\footnotetext{
${ }^{22}$ In addition, there is some evidence that matching schemes might become less effective over time as donors are given repeated opportunities to give [Meier 2007]. Such effects might exist in the long run if pro-social behavior is undermined by the provision of incentives [Benabou and Tirole 2006].
} 
receives little feedback on alternative approaches. In line with recent evidence on for-profit firms [Levitt 2006], absent informative feedback on alternative fundraising schemes, systematic deviations from optimal fundraising methods can persist. On this point, we view the nascent body of evidence from large scale field experiments as providing credible information from which other charitable organizations can learn. This point would be further reinforced if our results are shown to have external validity in other settings. Along these lines, we reiterate that when we replicate the method of Karlan and List [2007] to estimate price elasticities, we find very similar estimates, despite the two studies taking place in different countries, in different time periods, and targeting individuals with likely different observable characteristics. This should encourage other researchers to go and continue to use field experiments, in conjunction with other research designs, to better understand the economics of giving.

\section{References}

[1] Andreoni.J (1990) "Impure Altruism and Donations to Public Goods: A Theory of WarmGlow Giving", Economic Journal 100: 464-77.

[2] Andreoni.J (1998) "Toward a Theory of Charitable Fund-Raising", Journal of Political Economy 106: 1186-213.

[3] Andreoni.J And J.H.miller (2002) "Giving According to GARP: An Experimental Test of the Consistency of Preferences for Altruism", Econometrica 70: 737-53.

[4] Andreoni.J (2006a) "Philanthropy", in The Handbook of Giving, Reciprocity and Altruism, S.C.Kolm and J.Mercier Ythier (eds.), Amsterdam: North Holland.

[5] Andreoni.J (2006b) "Leadership Giving in Charitable Fund-Raising", Journal of Public Economic Theory 8: 1-22.

[6] Andreoni.J And R.Petrie (2004) "Public Goods Experiments Without Confidentiality: A Glimpse Into Fund-Raising", Journal of Public Economics 88: 1605-23.

[7] Angrist.J.D (1997) "Conditional Independence in Sample Selection Models", Economics Letters 54: 103-12.

[8] Auten.G.E, J.m.Cilke And W.C.RAndolph (1992) "The Effects of Tax Reform on Charitable Contributions", National Tax Journal 45: 267-90.

[9] Auten.G, H.Sieg, And C.t.Clotfelter (2002) "Charitable Giving, Income, and Taxes: An Analysis of Panel Data", American Economic Review 92: 371-82.

[10] BEKKERs.R (2005) When and Why Matches are More Effective Subsidies Than Rebates, mimeo, Utrecht University. 
[11] Benabou.r And J.TiRole (2006) "Incentives and Prosocial Behavior", Review of the Economic Studies 96: 1652-78.

[12] Benz.m And s.meier (2008) "Do People Behave in Experiments as in the Field?-Evidence from Donations", Experimental Economics 11: 268-81.

[13] CERmak.D, K.M.File And R.A.Prince (1994) "A Benefit Segmentation of the Major Donor Market", Journal of Business Research 29: 121-30.

[14] Chen.y, X.Li And J.K.mackie-Mason (2006) "Online Fund-Raising Mechanisms", Contributions to Economic Analysis and Policy 5: Article 4.

[15] Clotfelter.c.T (1985) Federal Tax Policy and Charitable Giving, University of Chicago Press: Chicago.

[16] Council For Advancement And support of Education (1999) 1999 Matching Gift Statistics, New York: Council for Advancement and Support of Education, Matching Gift Clearinghouse.

[17] De Oliveira.A.C.M, R.T.A.Croson And C.ECkel (2010) The Giving Type: Identifying Donors, mimeo, University of Texas at Dallas.

[18] Deaton.a (1985) "Panel Data from a Time Series of Repeated Cross Sections", Journal of Econometrics 53: 503-43.

[19] Dove.K.E (2000) Conducting a Successful Capital Campaign (2nd Edition), Jossey-Bass: San Francisco, CA.

[20] ECKel.C And P.Grossman (2003) "Rebate Versus Matching: Does How We Subsidize Charitable Contributions Matter?", Journal of Public Economics 87: 681-701.

[21] ECKel.C And P.grossman (2006) Subsidizing Charitable Giving: A Field Test Comparing Matching and Rebate Subsidies, mimeo, Virginia Tech.

[22] FACK.G AND C.LAndais (2009) "Are Fiscal Incentives Towards Charitable Giving Efficient? Evidence from France", forthcoming, American Economic Journal: Economic Policy.

[23] FALK.A (2007) "Gift-Exchange in the Field", Econometrica 75: 1501-12.

[24] Falk.a And M.Kosfeld (2006) "The Hidden Cost of Control", American Economic Review 96: 1611-30.

[25] Feldstein.m.s (1975) "The Income Tax and Charitable Contributions: Part II-The Impact on Religious, Educational, and Other Organizations", National Tax Journal 28: 209-26.

[26] FREy.B.S AND S.MeIER (2004) "Social Comparisons and Pro-social Behavior: Testing 'Conditional Cooperation' in a Field Experiment", American Economic Review 94: 1717-22. 
[27] GLAZER.A AND K.A.KOnRAD (1996) "A Signalling Explanation for Private Charity", American Economic Review 86: 1019-28.

[28] HirAno.K, G.W.imbens And G.RIDder (2003) "Efficient Estimation of Average Treatment Effects Using the Estimated Propensity Score", Econometrica 71: 1161-89.

[29] HUCK.S AND I.RASUl (2009) Comparing Charitable Fundraising Schemes: Evidence from a Natural Field Experiment, mimeo UCL.

[30] HUCK.S AND I.RASUl (2010) "Transactions Costs in Charitable Giving: Evidence from Two Field Experiments", The B.E. Journal of Economic Analysis and Policy, 10 (Advances), Article 31.

[31] Karlan.D And J.A.List (2007) "Does Price Matter in Charitable Giving? Evidence from a Large-Scale Natural Field Experiment", American Economic Review 97: 1774-93.

[32] KELLEY.K.S (1997) "From Motivation to Mutual Understanding: Shifting the Domain of Donor Research", in Critical Issues in Fundraising, D.Burlingame (ed.), Wiley: New York.

[33] LANDRY.C, A.LANGE, J.A.LIST, M.K.PRICE, AND N.RUPP (2006) "Towards an Understanding of the Economics of Charity: Evidence from a Field Experiment", Quarterly Journal of Economics 121: 747-82.

[34] LEvitT.S.D (2006) An Economist Sells Bagels: A Case Study in Profit Maximization, NBER Working Paper 12152.

[35] List.J.A AND D.LuCKing-REIley (2002) "The Effects of Seed Money and Refunds on Charitable Giving: Experimental Evidence from a University Capital Campaign", Journal of Political Economy 110: 215-33.

[36] MEIER.S (2007) "Do Subsidies Increase Charitable Giving in the Long Run? Matching Donations in a Field Experiment", Journal of the European Economic Association 5: 1203-22.

[37] Peloza.J And P.STeel (2005) "The Price Elasticities of Charitable Contributions: A MetaAnalysis", Journal of Public Policy and Marketing 24: 260-72.

[38] Potters.J, m.Sefton, And L.Vesterlund (2007) "Leading-by-Example and Signaling in Voluntary Contribution Games: An Experimental Study", Economic Theory 33: 169-82.

[39] Randolph.w.C (1995) "Dynamic Income, Progressive Taxes, and the Timing of Charitable Contributions", Journal of Political Economy 103: 709-38.

[40] Romano.R And H.yildirim (2001) "Why Charities Announce Donations: A Positive Perspective", Journal of Public Economics 81: 423-47.

[41] RONDEAU.D AND J.A.List (2008) "Matching and Challenge Gifts to Charity: Evidence from Laboratory and Natural Field Experiments", Experimental Economics 11: 253-81. 
[42] Rose-ackerman.s (1986) "Do Government Grants to Charity Reduce Private Donations?", in R.Ackerman (ed.) The Economics of Nonprofit Fundraising, Oxford University Press: New York.

[43] Rousseau.D.m (1995) Psychological Contracts in Organizations: Understanding Written and Unwritten Agreements, Sage Publications: Newbury Park, CA.

[44] Shang.J And R.Croson (2009) "Field Experiments in Charitable Contribution: The Impact of Social Influence on the Voluntary Provision of Public Goods", forthcoming The Economic Journal.

[45] Taussig.m.K (1967) "Economic Aspects of the Personal Tax Treatment of Charitable Contributions", National Tax Journal 20: 1-19.

[46] Tienen.l (2001) "Tax Policy and Charitable Contributions of Money", National Tax Journal 54: 707-23.

[47] Vesterlund.l (2003) "The Informational Value of Sequential Fundraising", Journal of Public Economics 87: 627-57.

[48] Wooldridge.J.m (2002) Econometric Analysis of Cross Section and Panel Data, Cambridge, Mass.: MIT Press. 


\section{Table 1: Characteristics of Recipients by Matching Treatment}

Mean, standard error in parentheses

P-value on test of equality of means with control group TO in brackets

\begin{tabular}{|c|c|c|c|c|c|c|c|c|c|c|}
\hline $\begin{array}{l}\text { Treatment } \\
\text { Number }\end{array}$ & Treatment Description & $\begin{array}{c}\text { Number of } \\
\text { Individuals } \\
\text { (1) }\end{array}$ & $\begin{array}{c}\text { Female } \\
\text { [Yes=1] } \\
(2)\end{array}$ & $\begin{array}{c}\text { Number of } \\
\text { Tickets Bought in } \\
\text { Last } 12 \text { Months } \\
\text { (3) }\end{array}$ & $\begin{array}{c}\text { Number of } \\
\text { Ticket Orders in } \\
\text { Last } 12 \text { Months } \\
\text { (4) }\end{array}$ & $\begin{array}{l}\text { Average Price of } \\
\text { Tickets Bought in } \\
\text { Last } 12 \text { Months } \\
\text { (5) }\end{array}$ & $\begin{array}{l}\text { Total Value of All } \\
\text { Tickets Bought in } \\
\text { Last } 12 \text { Months } \\
\text { (6) }\end{array}$ & $\begin{array}{c}\text { Munich } \\
\text { Resident } \\
\text { [Yes=1] } \\
(7)\end{array}$ & $\begin{array}{c}\text { Year of Last } \\
\text { Ticket Purchase } \\
{[2006=1]} \\
\text { (8) }\end{array}$ & $\begin{array}{c}\text { Rental } \\
\text { Prices } \\
2006 \\
(9)\end{array}$ \\
\hline T0 & Control & 3787 & $\begin{array}{c}.466 \\
(.008)\end{array}$ & $\begin{array}{c}6.30 \\
(.178)\end{array}$ & $\begin{array}{c}2.23 \\
(.047)\end{array}$ & $\begin{array}{c}86.6 \\
(.666)\end{array}$ & $\begin{array}{c}416 \\
(7.88)\end{array}$ & $\begin{array}{c}.416 \\
(.008)\end{array}$ & $\begin{array}{c}.565 \\
(.008)\end{array}$ & $\begin{array}{c}11.2 \\
(.021)\end{array}$ \\
\hline T1 & Lead donor & 3770 & $\begin{array}{l}.478 \\
(.008) \\
{[.269]}\end{array}$ & $\begin{array}{l}6.27 \\
(.153) \\
{[.886]}\end{array}$ & $\begin{array}{l}2.22 \\
(.046) \\
{[.838]}\end{array}$ & $\begin{array}{c}86.3 \\
(.650) \\
{[.722]}\end{array}$ & $\begin{array}{c}423 \\
(7.73) \\
{[.541]}\end{array}$ & $\begin{array}{l}.416 \\
(.008) \\
{[.980]}\end{array}$ & $\begin{array}{l}.574 \\
(.008) \\
{[.420]}\end{array}$ & $\begin{array}{l}11.2 \\
(.021) \\
{[.979]}\end{array}$ \\
\hline T2 & Lead donor + 1:.5 match & 3745 & $\begin{array}{l}.481 \\
(.008) \\
{[.182]}\end{array}$ & $\begin{array}{l}6.39 \\
(.184) \\
{[.737]}\end{array}$ & $\begin{array}{l}2.20 \\
(.049) \\
{[.700]}\end{array}$ & $\begin{array}{l}86.8 \\
(.660) \\
{[.873]}\end{array}$ & $\begin{array}{c}432 \\
(9.63) \\
{[.197]}\end{array}$ & $\begin{array}{l}.416 \\
(.008) \\
{[.991]}\end{array}$ & $\begin{array}{l}.576 \\
(.008) \\
{[.329]}\end{array}$ & $\begin{array}{l}11.2 \\
(.021) \\
{[.905]}\end{array}$ \\
\hline T3 & Lead donor + 1:1 match & 3718 & $\begin{array}{l}.477 \\
(.008) \\
{[.314]}\end{array}$ & $\begin{array}{l}6.46 \\
(.148) \\
{[.496]}\end{array}$ & $\begin{array}{c}2.28 \\
(.050) \\
{[.439]}\end{array}$ & $\begin{array}{l}85.8 \\
(.667) \\
{[.397]}\end{array}$ & $\begin{array}{c}435 \\
(9.78) \\
{[.124]}\end{array}$ & $\begin{array}{l}.419 \\
(.008) \\
{[.819]}\end{array}$ & $\begin{array}{l}.576 \\
(.008) \\
{[.347]}\end{array}$ & $\begin{array}{c}11.2 \\
(.021) \\
{[.785]}\end{array}$ \\
\hline
\end{tabular}

Notes: All figures refer to the mail out recipients in each treatment excluding non-German residents, corporate donors, formally titled donors, and recipients to whom no gender can be assigned. The tests of equality are based on an OLS regression allowing for robust standard errors. All monetary amounts are measured in Euros. In Columns 3 to 6 the "last twelve months" refers to the year prior to the mail out from June 2005 to June 2006 . In Column 9 , the 
Table 2: Characteristics of Donors and Non Donors by Matching Treatment

Mean, standard error in parentheses

P-value on test of equality of means for donors and non-donors in the same treatment in brackets

\begin{tabular}{|c|c|c|c|c|c|c|c|c|c|c|c|c|}
\hline \multicolumn{2}{|c|}{ Treatment Number and Description } & Comparison Group & $\begin{array}{c}\text { Number } \\
\text { (Proportion) } \\
\text { of Responses } \\
\text { (1) }\end{array}$ & $\begin{array}{c}\text { Response } \\
\text { Rate } \\
\text { (2) }\end{array}$ & $\begin{array}{c}\text { Female } \\
\text { [Yes=1] } \\
\text { (3) }\end{array}$ & $\begin{array}{l}\text { Number of Tickets } \\
\text { Bought in Last } 12 \\
\text { Months } \\
\text { (4) }\end{array}$ & $\begin{array}{c}\text { Number of } \\
\text { Ticket Orders in } \\
\text { Last } 12 \text { Months } \\
\text { (5) }\end{array}$ & $\begin{array}{l}\text { Average Price of } \\
\text { Tickets Bought in } \\
\text { Last } 12 \text { Months } \\
\text { (6) }\end{array}$ & $\begin{array}{l}\text { Total Value of All } \\
\text { Tickets Bought in } \\
\text { Last } 12 \text { Months } \\
\text { (7) }\end{array}$ & $\begin{array}{c}\text { Munich } \\
\text { Resident } \\
\text { [Yes=1] } \\
\text { (8) }\end{array}$ & $\begin{array}{c}\text { Year of Last } \\
\text { Ticket Purchase } \\
\text { [2006=1] } \\
\text { (9) }\end{array}$ & $\begin{array}{r}\text { Renta } \\
\text { Prices } \\
2006 \\
(10)\end{array}$ \\
\hline \multirow{2}{*}{\multicolumn{3}{|c|}{ Entire sample (donors and non donors) }} & 585 & .039 & .475 & 6.35 & 2.23 & 86.4 & 426 & .417 & .573 & 11.2 \\
\hline & & & $(100)$ & & $(.004)$ & $(.083)$ & $(.024)$ & $(.330)$ & $(4.40)$ & $(.004)$ & $(.004)$ & $(.011)$ \\
\hline \multirow[t]{3}{*}{ TO } & Control & & 142 & .037 & .394 & 8.55 & 2.87 & 87.1 & 585 & .380 & .697 & 11.2 \\
\hline & & \multirow{2}{*}{\multicolumn{2}{|c|}{$\begin{array}{r}(15.4) \\
\text { Non Donors in Same Treatment }\end{array}$}} & $(.003)$ & $(.041)$ & $(.970)$ & $(.245)$ & (3.65) & $(47.0)$ & $(.041)$ & $(.039)$ & $(.108)$ \\
\hline & & & & & {$[.080]$} & {$[.019]$} & {$[.009]$} & {$[.901]$} & {$[.000]$} & {$[.376]$} & {$[.000]$} & {$[.855]$} \\
\hline \multirow[t]{3}{*}{ T1 } & Lead donor & & 132 & .035 & .530 & 9.52 & 3.36 & 88.1 & 666 & .394 & .742 & 11.3 \\
\hline & & & (14.3) & $(.003)$ & $(.044)$ & $(.954)$ & $(.374)$ & $(4.21)$ & $(66.1)$ & $(.043)$ & $(.038)$ & $(.114)$ \\
\hline & & \multicolumn{2}{|c|}{ Non Donors in Same Treatment } & & {$[.226]$} & {$[.000]$} & {$[.002]$} & {$[.669]$} & {$[.000]$} & {$[.600]$} & {$[.000]$} & [.386] \\
\hline \multirow[t]{3}{*}{ T2 } & Lead donor $+1: .5$ match & & 156 & .042 & .449 & 9.67 & 2.88 & 87.3 & 662 & .365 & .654 & 11.2 \\
\hline & & & $(16.9)$ & $(.003)$ & $(.040)$ & $(1.09)$ & $(.235)$ & (3.33) & $(55.1)$ & $(.039)$ & $(.038)$ & $(.113)$ \\
\hline & & \multicolumn{2}{|c|}{ Non Donors in Same Treatment } & & [.412] & {$[.002]$} & {$[.004]$} & {$[.874]$} & {$[.000]$} & [.183] & {$[.040]$} & [.673] \\
\hline \multirow[t]{3}{*}{ T3 } & Lead donor $+1: 1$ match & & 155 & .042 & .426 & 7.96 & 2.75 & 88.9 & 619 & .413 & .748 & 11.2 \\
\hline & & & (16.8) & $(.003)$ & $(.040)$ & $(.746)$ & $(.274)$ & $(4.13)$ & $(58.2)$ & $(.040)$ & $(.035)$ & $(.108)$ \\
\hline & & \multicolumn{2}{|c|}{ Non Donors in Same Treatment } & & {$[.190]$} & {$[.041]$} & {$[.083]$} & {$[.452]$} & {$[.001]$} & {$[.886]$} & {$[.000]$} & {$[.957]$} \\
\hline
\end{tabular}

Notes: All figures refer to the mail out recipients in each treatment excluding non-German residents, corporate donors, formally titled donors, and recipients to whom no gender can be assigned. The first row refers to all recipients (donors and non donors) across all treatments To to T3. The tests of equality are based on an OLS regression allowing for robust standard errors. All monetary amounts are measured in Euros. In Column 1 , the proportion refers to the proportion or
the "last twelve months" refers to the year prior to the mail out from June 2005 to June 2006. In Column 10, the rental price measure is the price of renting a flat measured in Euros per month per square meter. 


\section{Table 3: Outcomes by Treatment}

\section{Mean, standard error in parentheses}

P-values on tests of equalities on means with comparison group in brackets

\begin{tabular}{|c|c|c|c|c|c|c|c|c|c|}
\hline $\begin{array}{l}\text { Treatment } \\
\text { Number }\end{array}$ & Treatment Description & $\begin{array}{c}\text { Comparison } \\
\text { Group }\end{array}$ & $\begin{array}{c}\text { Response Rate } \\
\text { (1) }\end{array}$ & $\begin{array}{l}\text { Total Amount } \\
\text { Donated } \\
\text { (2) }\end{array}$ & $\begin{array}{c}\text { Total Amount } \\
\text { Raised } \\
\text { (3) }\end{array}$ & $\begin{array}{c}\text { Average } \\
\text { Donation } \\
\text { Received } \\
\text { (4) }\end{array}$ & $\begin{array}{c}\text { Median } \\
\text { Donation } \\
\text { Received } \\
\text { (5) }\end{array}$ & $\begin{array}{c}\text { Average } \\
\text { Donation } \\
\text { Given } \\
(6)\end{array}$ & $\begin{array}{l}\text { Median } \\
\text { Donation } \\
\text { Given } \\
(7)\end{array}$ \\
\hline TO & Control & & $\begin{array}{c}.037 \\
(.003)\end{array}$ & 10550 & 10550 & $\begin{array}{c}74.3 \\
(6.19)\end{array}$ & 50 & $\begin{array}{c}74.3 \\
(6.19)\end{array}$ & 50 \\
\hline \multirow[t]{2}{*}{ T1 } & Lead donor & & $\begin{array}{c}.035 \\
(.003)\end{array}$ & 17416 & 17416 & $\begin{array}{c}132 \\
(14.3)\end{array}$ & 100 & $\begin{array}{c}132 \\
(14.3)\end{array}$ & 100 \\
\hline & & T0 Control & {$[.564]$} & & & {$[.000]$} & {$[.000]$} & {$[.000]$} & {$[.000]$} \\
\hline \multirow[t]{3}{*}{ T2 } & Lead donor + 1:.5 matching & & $\begin{array}{c}.042 \\
(.003)\end{array}$ & 15705 & 23558 & $\begin{array}{c}151 \\
(18.9)\end{array}$ & 75 & $\begin{array}{c}101 \\
(12.6)\end{array}$ & 50 \\
\hline & & T0 Control & {$[.355]$} & $15 / 05$ & 23558 & {$[.000]$} & {$[.005]$} & {$[.061]$} & [.999] \\
\hline & & T1 Lead donor & {$[.134]$} & & & {$[.421]$} & {$[.131]$} & {$[.102]$} & {$[.000]$} \\
\hline \multirow[t]{4}{*}{ T3 } & Lead donor + 1:1 matching & & .042 & & & 185 & 100 & 92.3 & 50 \\
\hline & & & $(.003)$ & 14310 & 28620 & $(20.7)$ & & $(10.4)$ & \\
\hline & & T0 Control & [.352] & & & {$[.000]$} & {$[.000]$} & {$[.136]$} & [.999] \\
\hline & & T1 Lead donor & {$[.132]$} & & & {$[.037]$} & {$[.999]$} & {$[.025]$} & {$[.000]$} \\
\hline
\end{tabular}

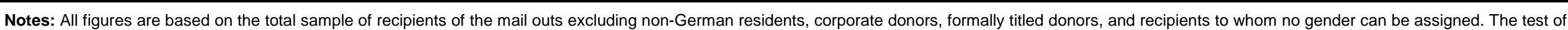

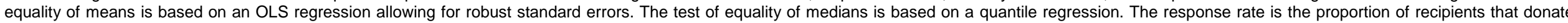

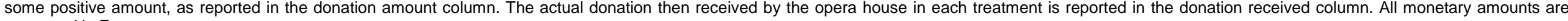
measured in Euros. 
Table 4: Linear Matching Schemes

Marginal effects reported in probit regressions

Robust standard errors in parentheses

Dependent variable:

Any Donation Made

Donation Received

gonation Received)

Donation Received

Log (Donation Given)

(1) Probi

(2) OLS

(3) Hurdle Model

(4) Tobit Model

(5) Cross Price Elasticity
of Own Consumption

Karlan-List [2007]

Lead donor + 1:.5 matching T2

.007

1.61

.178
$(.128)$

$39.6^{*}$

$-.301^{* *}$

Lead donor + 1:1 matching T3

.007

(1.12)

$.457^{* * *}$

(.124)

$44.8^{*}$

(.127)

(1.22)

157

(23.7)

$-.354^{\star * *}$

.040

.039

6.20

157

(.125)

(.108)

Mean of Dependent Variable

$-.534(.385)$

t-test: pure warm glow

t-test: donation targeting

Implied Own Price Elasticity [ T2 - T3 ]

t-test: pure warm glow

t-test: donation targeting

[.167]

$-1.12(.444)$

[.047]

[.012]

Implied Own Price Elasticity [ T1 - T3 ]

t-test: pure warm glow

-.915 (.249)

t-test: donation targeting

[.000]

Implied Cross Price Elasticity [ T1 - T2 ]

Implied Cross Price Elasticity [ T1 - T3 ]

Implied Cross Price Elasticity [ T1 - T2 ]

Implied Cross Price Elasticity [ T0 - T3 ]

Implied Cross Price Elasticity [ T0 - T4 ]

Implied Cross Price Elasticity [ T0 - T4 ]

Observations

11233

11233

443

Notes: ${ }^{* \star *}$ denotes significance at $1 \%,{ }^{* \star}$ at $5 \%$, and ${ }^{*}$ at $10 \%$. Robust standard errors estimated throughout. In Column 1 a probit regression is estimated where the dependent variable is equal to one if the recipient responds to the treatment with any positive donation, and zero otherwise. Marginal effects evaluated at the sample mean of all other variables are reported. The sample in Columns 1 and 2 is based on observations from treatments T1, T2 and T3. In Columns 3,5 and 6 the second stage of a hurdle model is estimated assuming the donation amounts and received follow a log normal distribution. In Column 4 a Tobit model is estimated. The dependent variable in Columns 2 and 4 (3) is the donation received (log of the donation received), and the dependent variable in Columns 5 and 6 is the log of the donation given. The reference treatment group in Columns 1 to 5 is the lead donor treatment (T1), and in Column 6 the reference treatment group is the control treatment (TO). In Columns 3,5 and 6 the implied own and cross price elasticities are reported and the standard error of each estimate is reported in parentheses. All specifications control for the 
Figure 1: The Design of the Field Experiment and Outcomes

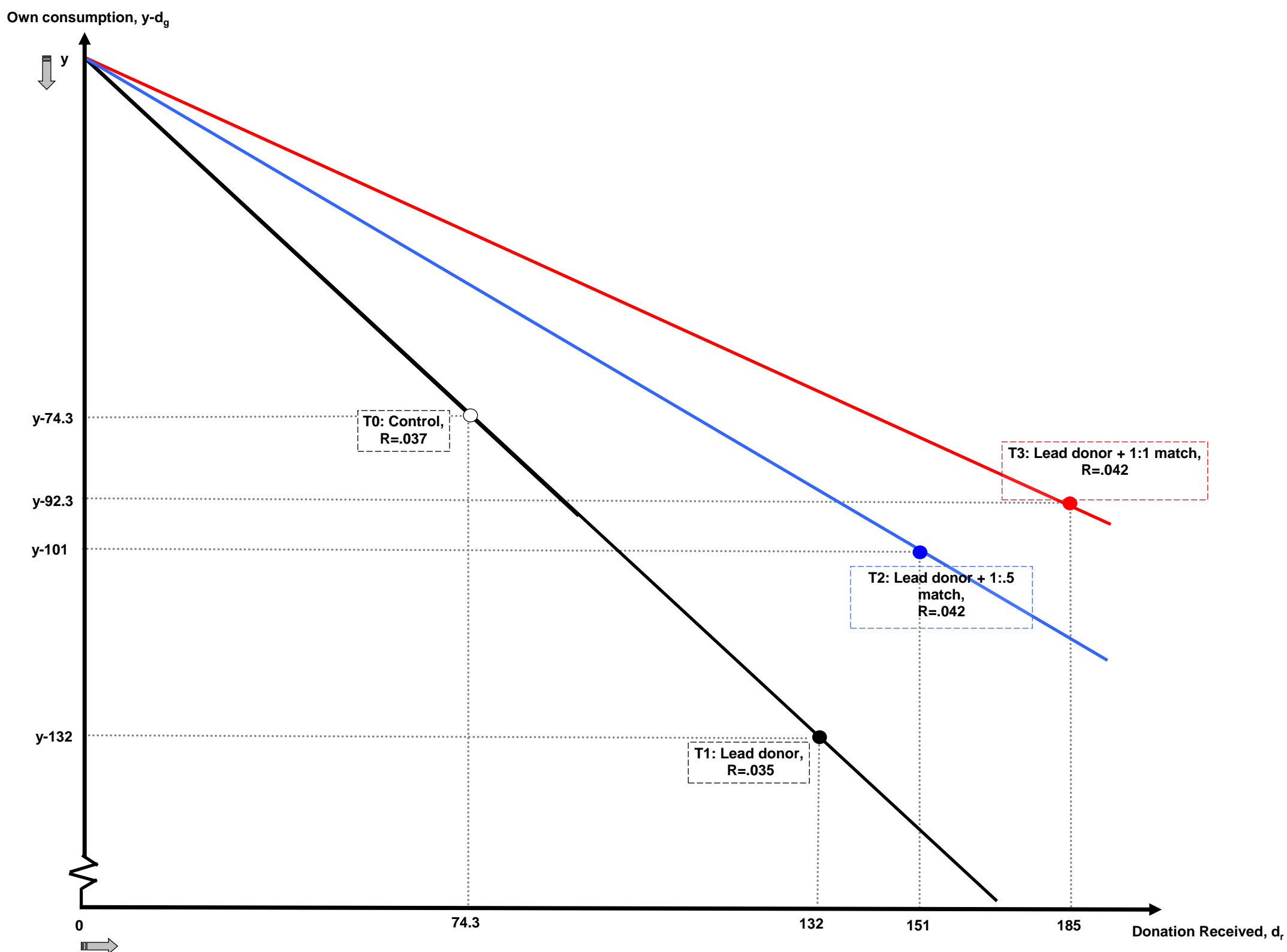




\section{Figure 2: Predictions}

Own Price Elasticity of Donations Received $\left(\varepsilon_{\mathrm{dr}, \mathrm{p}}\right)$

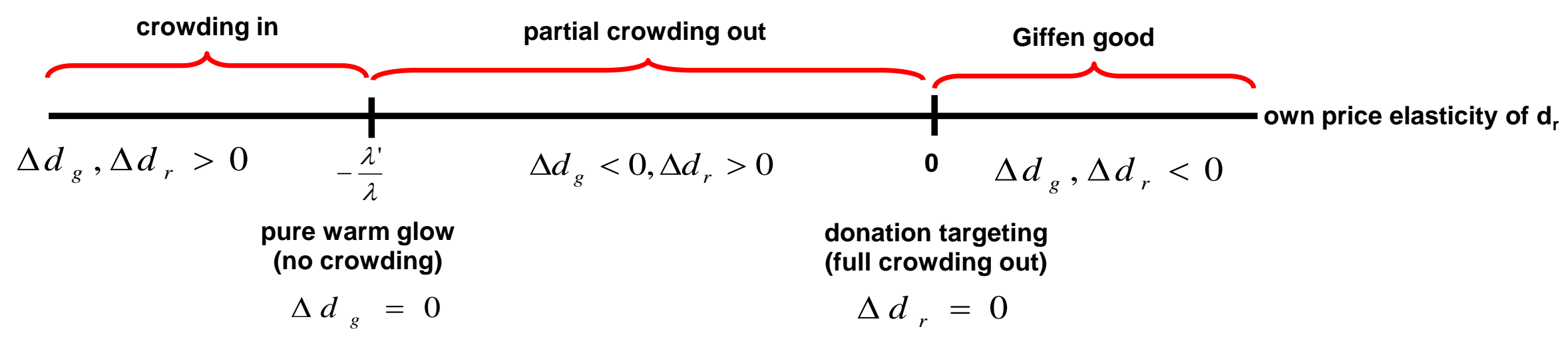


Figure 3: Cumulative Distribution of Donation Given, by Treatment

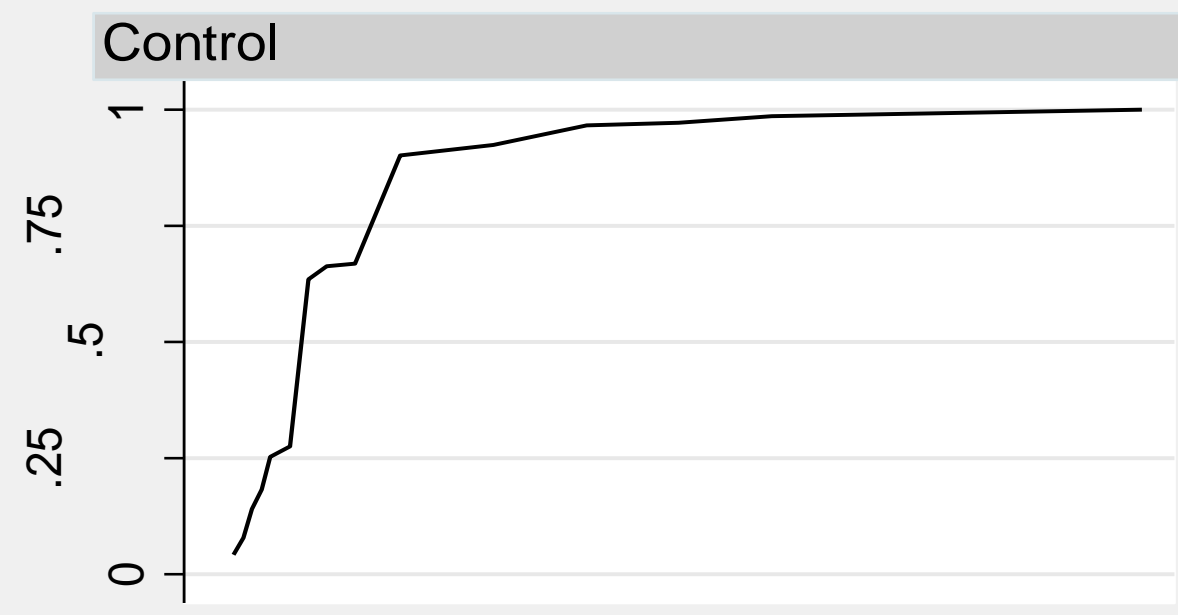

\section{Lead Donor}
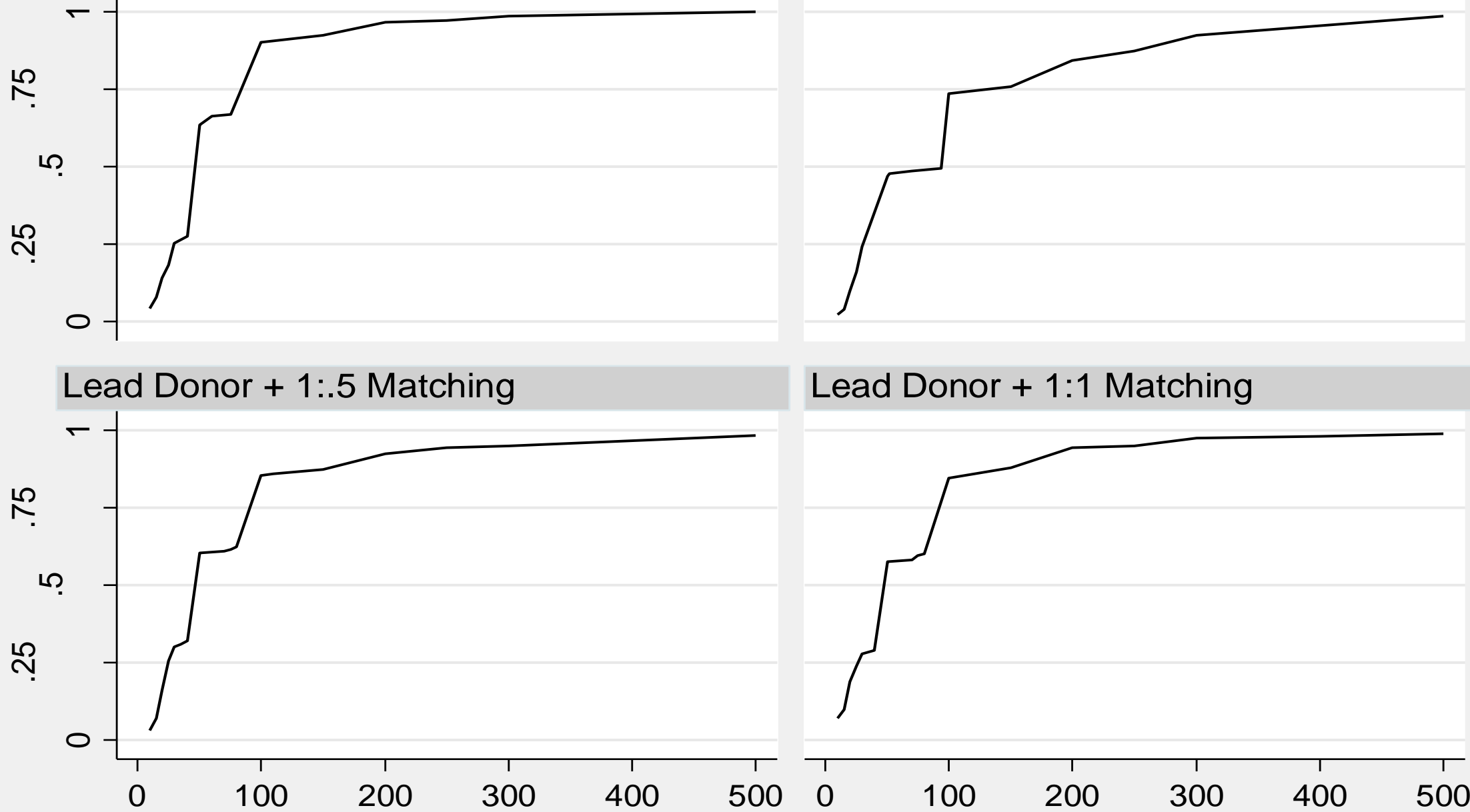

\section{Lead Donor + 1:1 Matching}

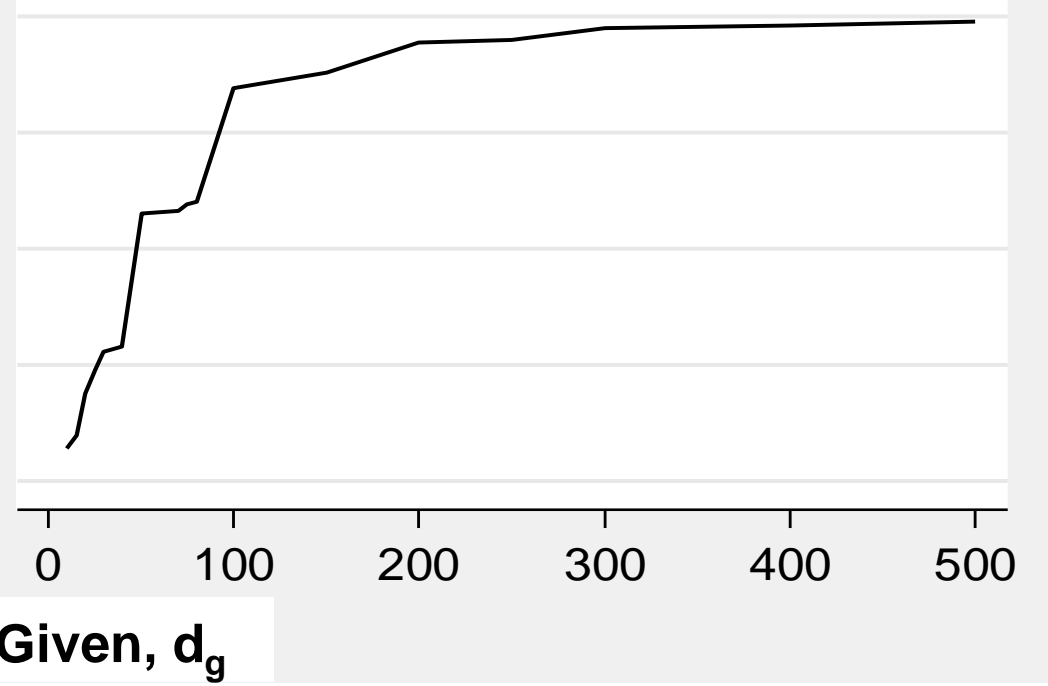

Notes: Each figure shows the cumulative distribution of donations given in each treatment. To aid exposition, each figure is capped at donations of $€ 500$ 


\section{Appendix: The Mail Out Letter (Translated)}

Bayerische Staatsoper

Staatsintendant

Max-Joseph-Platz 2, D-80539 München

www.staatsoper.de

\section{[ADDRESS OF RECIPIENT]}

\section{Dear [RECIPIENT],}

The Bavarian State Opera House has been investing in the musical education of children and youths for several years now as the operatic the art form is in increasing danger of disappearing from the cultural memory of future generations.

Enthusiasm for music and opera is awakened in many different ways in our children and youth programme, "Erlebnis Oper" [Experience Opera]. In the forthcoming season 2006/7 we will enlarge the scope of this programme through a new project "Stück für Stück" that specifically invites children from schools in socially disadvantaged areas to a playful introduction into the world of opera. Since we have extremely limited own funds for this project, the school children will only be able to experience the value of opera with the help of private donations.

[This paragraph describes each matching scheme and is experimentally varied as described in the main text of the paper].

As a thank you we will give away a pair of opera tickets for Engelbert Humperdinck's "Konigskinder" on Wednesday, 12 July 2006 in the music director's box as well as fifty CDs signed by Maestro Zubin Mehta among all donors.

You can find all further information in the enclosed material. In case of any questions please give our Development team a ring on [phone number]. I would be very pleased if we could enable the project "Stück für Stück" through this appeal and, thus, make sure that the operatic experience is preserved for younger generations.

With many thanks for your support and best wishes,

Sir Peter Jonas, Staatsintendant 


\section{Appendix: The Mail Out Letter (Translated)}

\section{“Stück für Stück”}

The project "Stück für Stück" has been developed specifically for school children from socially disadvantaged areas. Musical education serves many different functions in particular for children and youths with difficult backgrounds -- it strengthens social competence and own personality, improves children's willingness to perform, and reduces social inequality. Since music education plays a lesser and lesser role in home and school education, the Bavarian State Opera has taken it on to contribute to it ourselves. The world of opera as a place of fascination is made attainable and accessible for young people.

In drama and music workshops, "Stück für Stück” will give insights into the world of opera for groups of around 30 children. They will be intensively and creatively prepared for a subsequent visit of an opera performance. These workshops encourage sensual perception - through ear and eye but also through scenic and physical play and intellectual comprehension - all of these are important elements for the workshops. How does Orpheus in "Orphee and Eurydice" manage to persuade the gods to let him save his wife from the realm of dead? Why does he fail? Why poses the opera "Cosi fan tutte" that girls can never be faithful? It is questions like these that are investigated on the workshops.

The workshops are also made special through the large number and variety of people who are involved in them: musicians, singers, directors, and people from many other departments, ranging from costumes and makeup to marketing. The participants in each workshop work through an opera's storyline, and are introduced to the production and will meet singers in their costumes as well as musicians. This makes the workshops authentic. After the workshops the participants are invited to see the actual opera production.

Through your donation the project "Stück für Stück" will be made financially viable so that we can charge only a small symbolic fee to the participants. This makes it possible to offer our children and youth programme also to children from socially disadvantaged backgrounds that can, thus, learn about the fascination of opera.

Note: In German, Stück für Stück is a wordplay --- "Stück” meaning "play" as in drama and "Stück für Stück" being an expression for doing something bit by bit. 